\title{
Application of tamarind seed starch as edible coating in the post-harvest quality of grapes 'Isabel' (Vitis Iabrusca $\times$ Vitis vinifera L.)
}

\author{
Bárbara Genilze Figueiredo Lima Santos ${ }^{1}$, Albert Einstein Mathias de Medeiros Teodosio*2, Railene Hérica \\ Carlos Rocha Araújo', Elny Alves Onias', Agda Malany Forte de Oliveira', Elidayane da Nóbrega Santos', \\ Rita Magally Oliveira da Silva Marcelino', Jaína Geovana Figueiredo Lima Santos ${ }^{1}$
}

\author{
${ }^{1}$ Federal University of Campina Grande, Pombal, Paraíba, Brazil \\ ${ }^{2}$ Federal University of Paraíba, Areia, Paraíba, Brazil
}

\section{*Corresponding author: albertemmt@gmail.com}

\section{Abstract}

The Isabel grape (Vitis labrusca $\times$ Vitis vinifera L.) is the most produced grape in Brazil, however, it has a short postharvest period due to rapid degradation during storage. The use of coating has been an alternative to prolong the shelf-life of fruits. The objective of this work was to evaluate the postharvest quality of 'Isabel' grapes coated with tamarind (Tamarindus indica L.) seed starch. The experimental design was completely randomized with five treatments with edible coating based on tamarind seed starch, at concentrations of $0,0.5,1,1.5$ and $2 \%$ and five replications. The grapes were immersed in the solutions with different concentrations and stored in B.O.D. at $12 \pm 2{ }^{\circ} \mathrm{C}$ and $85 \pm 5 \%$ relative humidity for 12 days. Weight loss, color, pH, soluble solids, total titratable acidity, relationship between soluble solids and acidity, anthocyanins, flavonoids and vitamin $\mathrm{C}$ were evaluated. The $2 \%$ coating of tamarind seed starch was the most efficient, providing shelf life in 12 -day grapes when stored at $12 \pm 2{ }^{\circ} \mathrm{C}$ and $85 \pm$ $5 \% \mathrm{RH}$, and maintaining the main quality aspects, with higher SS / TA ratio and vitamin C.

Keywords: Shelf-life; storage; Tamarindus indica L.; vitamin C; Vitis labrusca $\times$ Vitis vinifera $\mathrm{L}$.

Abbreviations: TSS_tamarind seed starch RH_relative humidity; B.O.D_Biochemical oxygen demand; DF_degree of freedom; CV_coefficient of variation; WL_weight loss; L*_luminosity; C*_chromaticity; Ho_angle hue; SS_soluble solids; AT_acidity titratable; SS/AT_ratio; $\mathrm{pH} \_$hydrogenation potential.

\section{Introduction}

The Isabel grape (syn. 'Isabella'), one of the most cultivated grapes in Brazil, is a hybrid cultivar of black grape (Vitis labrusca $\times$ Vitis vinifera L.), widely used as table grapes and in the preparation of juices and wines (Yamamoto et al., 2015; Maurer et al., 2017). This variety of grapes, although it is the most produced in Brazil, has problems related to its post-harvest shelf life, especially excessive degranulation, browning of the stalk, incidence of rot, loss of mass and softening of berries, and related problems packaging, handling and transportation (Silva et al., 2012; Guerra et al., 2016; Stocco et al., 2019). An important factor in the postharvest shelf life of table grapes is rapid senescence and color change, leading to losses during storage (Fakhouri et al., 2015; Chen et al., 2019). Different strategies have been applied to the post-harvest conservation of grapes, such as the application of edible gelatin coatings (Lemes et al., 2017) chitosan based (Melo et al., 2018). The edible coating is generally applied to ready-to-eat fresh fruits and vegetables with desirable physical, organoleptic and microbiological properties in order to delay their deterioration and prolong their shelf life (Poverenov et al., 2014; Yousuf et al. 2018). The use of storage under refrigeration decreases the physiological processes in the fruits. This reduces the incidence of degradation compared to fruit stored at room temperature. Therefore, the use of edible coatings combined with refrigeration may reduce fruit respiratory metabolism and physical mechanisms of water vapor transfer (Fakhouri et al., 2015; Wang et al., 2017). Starch has been widely used as a raw material in the preparation of edible coatings because it has good properties for biofilm formation (Eom et al., 2018). A viable alternative in the formulation of edible coatings is tamarind (Tamarindus indica L.) seed starch (TSS), because it is rich in proteins and polysaccharides, especially xyloglucan which is commercially used because of its thickening properties (Kai, 2009; Pereira, 2017). Although several studies have shown satisfactory results with the use of edible films and coatings, there is still a need to investigate the viability of materials with biological potential and properties essential for edible coating formation, such as microbiological safety, maintenance of color intensity and of the texture properties of vegetables. Therefore, due to the recognized biological potential of tamarind seed starch and its possible use in biofilm form, the objective of this work was to evaluate the postharvest quality of 'Isabel' grapes coated with tamarind seed starch.

\section{Results and discussion}

\section{Tamarind seed starch coating properties}

Biofilms tamarind seed starch-based are visually homogeneous and easily detachable from Petri dishes, and 
have good water solubility, indicating good performance in relation to the interaction of gelatinous complexes and structural chains of the coating (Figure 1). Edible coatings prepared with polysaccharides, particularly starches, contain various compounds that form the coating and provide a semipermeable barrier against humidity and oxygen, which reduces respiration rate and therefore delays vegetable ripening and senescence (Zhao, 2019).

The composition of the tamarind seed has many compounds that promote porous plasticity and grating of interaction of the carbohydrates with the protein complexes, which allows the formation of structuring chains mechanical and interactive on the surface of the fruit. The contents of starch and pectin in the tamarind seed are respectively 11.68 and $3.83 \%$, the main compounds responsible for gelling in the formation of edible coatings (Pereira, 2017). Part of these substances is responsible for promoting bioactive effects on fruits, especially in the regulation of transpiration and reduction of weight loss (Onias et al., 2019).

\section{Weight loss and epicarp staining}

The data obtained from the initial characterization of the grapes expressed in Table 1 shows satisfactory values for configuring the grapes within the marketing standard.

It was verified that there was a significant effect on the weight loss, epicarp color (luminosity, chromaticity and hue angle), soluble solids, titratable acidity, ratio, anthocyanins and vitamin $\mathrm{C}$, whereas for $\mathrm{pH}$ and flavonoid variables did not express a significant effect (Table 2).

The treatments with TSS coating maintained the fresh mass of Isabel grapes when compared to the control treatment, which lost $7.21 \%$ of its initial weight, higher than those found in treatments with $0.5(6.37 \%), 1$ (5.83\%), 1.5. (5.59\%) and $2 \%(5.67 \%)$ of the TSS (Figure $2 \mathrm{~A}$ ).

Frequently, fruits lose water to the atmosphere by gaseous exchanges through the pores. However, the TSS edible coating blocks part of the pores present in the grapes, reducing their respiratory rate and prevent loss of humidity. Similar results were found by Melo et al. (2018), working with an edible coating of fungal chitosan nanoparticles on table grapes, and also by Onias et al. (2019), who used an TSS edible coating associated with pomegranate seed oil in guavas. Coating with a thin edible layer can significantly reduce water loss, which is extremely important in fruit quality over the shelf life. Our findings have shown that TSS coating is effective in minimizing grape water loss during storage.

For the luminosity, there was an increasing linear behavior at the time the TSS coating concentrations were increased, with estimated values of 23.75, 24.61, 25.47 and 26.33 for the $0.5,1,1.5$, and $2.0 \%$ respectively and 22.89 for the control, showing more bright fruits in relation to the control (Figure 2B). In relation to the chromaticity of the peel presented in figure $(2 \mathrm{C})$, there was a trend of increase with estimated values of $1.27,1.47,1.67,1.88$ and 2.08 for the control and treatments at $0.5,1,1.5$, and $2.0 \%$ of TSS, respectively. As for the color tone $\left(\mathrm{H}^{\circ}\right)$ in the peel, there was a quadratic behavior, with estimated values of $0.44,0.34$, $0.31,0.36$ and 0.47 , respectively, for control and treatments with $0.5,1,1.5$, and $2.0 \%$ TSS (Figure 2D).

The luminosity is a parameter of great importance for the consumer, since the brightness is indicator of fresh fruit (Duarte et al., 2017). The edible coatings of TSS delay the senescence process of fruits when applied to grapes under refrigeration. Similar behavior found by Melo et al. (2018), in which the edible coating of fungal chitosan nanoparticles in table grapes presented higher values of $L^{*}$ in relation to the control.

The results infer that the color intensity of the grapes was not affected when coated in different concentrations. Therefore, as the concentrations of the coatings increase, a bright appearance predominates, with fruits more attractive in relation to the control. Effective edible coatings are those which, in addition to providing the appropriate water and gas barrier, hydrophobicity and wettability, should be attractive without compromising the organoleptic characteristics of the product to be marketed (Zhao, 2019).

\section{Physicochemical properties}

The soluble solids were conserved over the storage period with estimated values of $13.45,13.09,13.42$ and $14.44 \%$ for the $0.5,1,1.5$, and $2.0 \%$ coatings and $14.51 \%$ for the control, respectively (Figure $3 \mathrm{~A}$ ). Refrigeration has the potential to reduce fruit respiration, acting together with the coatings, contributed to the preservation of the soluble solids in the coated samples. Oh et al. (2017), evaluating chitosan-based edible coatings associated with lemon balm essential oil in improving microbiological safety and preservation of grape berries (Vitis vinifera L. $\times$ V. labruscana Bailey), did not observe significant differences in solids content soluble during storage at $4{ }^{\circ} \mathrm{C}$ for 28 days.

The titratable acidity was maintained during the storage period for the control $(0.82 \%)$ and for the coatings 0.5 and $1 \%(0.83$ and $0.80 \%)$, while in the 1.5 and $2 \%$ coatings there were a small reduction in acidity with estimated values of 0.73 and $0.61 \%$ respectively (Figure $3 B$ ). Acidity maintenance is an indication of the efficiency of the use of refrigeration with the use of edible coatings in delaying the consumption of important chemical components, such as fruit acidity (Melo et al., 2018). Therefore, it can be noticed that for the control treatment as well as for the coatings there were no major changes in relation to the acidity of the fruit. Vicentino et al. (2011) analyzing the effect of modified manioc starch coatings for the conservation of Benitaka grapes, observed that the titratable acidity was not altered between the control treatment and the coating over the storage.

The SS/AT ratio showed a quadratic behavior with the increase in coating concentrations, as a consequence of SS maintenance and reduction in AT, indicating that the $2 \%$ coating had the highest estimated value $(23.80)$ in relation to the other coatings $0.5,1$, and $1.5 \%(15.91,16.35$ and 18.98 , respectively) and the control 17.66 , indicating that the $2 \%$ coating gives it the sweetest grape flavor (Figure $3 \mathrm{C}$ ). The SS/AT ratio is indicative of grape flavor and acceptance, being an important post-harvest quality variable, since it expresses the balance between sweetness and acidity, representing in part a pleasant sensation on the consumer's palate (Mascarenhas et al., 2012).

\section{Bioactive compounds}

As for vitamin C, there is a linear trend increasing according to the increase of TSS coating concentrations, with estimated values of $2.78,3.16,3.53$ and $3.90 \mathrm{mg} 100 \mathrm{~g}^{-1}$ for the coatings $0.5,1,1.5$, and $2.0 \%$ and $2.41 \mathrm{mg} 100 \mathrm{~g}^{-1}$ for the control (Figure 4A). 
Table 1. Initial characterisation of 'Isabel' grapes before the application of the different coatings, UFCG, Pombal, 2018.

\begin{tabular}{|c|c|}
\hline Initials characteristics & Averages $\pm \mathrm{DP}$ \\
\hline Fresh mass of the fruit (g) & $150 \pm 1.84$ \\
\hline Luminosity & $26.22 \pm 1.49$ \\
\hline Chromaticity & $1.83 \pm 0.82$ \\
\hline Angle Hue ${ }^{\circ}$ & $0.07 \pm 0.42$ \\
\hline Hydrogen potential pH & $3.06 \pm 0.10$ \\
\hline Soluble solids (Brix ${ }^{\circ}$ ) & $14.0 \pm 0.76$ \\
\hline Titratable Acidity (\% de Tartaric acid) & $0.79 \pm 0.14$ \\
\hline Ratio SS/AT & $17.51 \pm 5.09$ \\
\hline Anthocyanins (mg $100^{-1}$ ) & $3.30 \pm 0.12$ \\
\hline Flavonoids (mg 100-1) & $1.49 \pm 0.18$ \\
\hline Vitamin C $\left({\left.\mathrm{mg} 100^{-1}\right)}\right.$ & $3.67 \pm 0.95$ \\
\hline
\end{tabular}

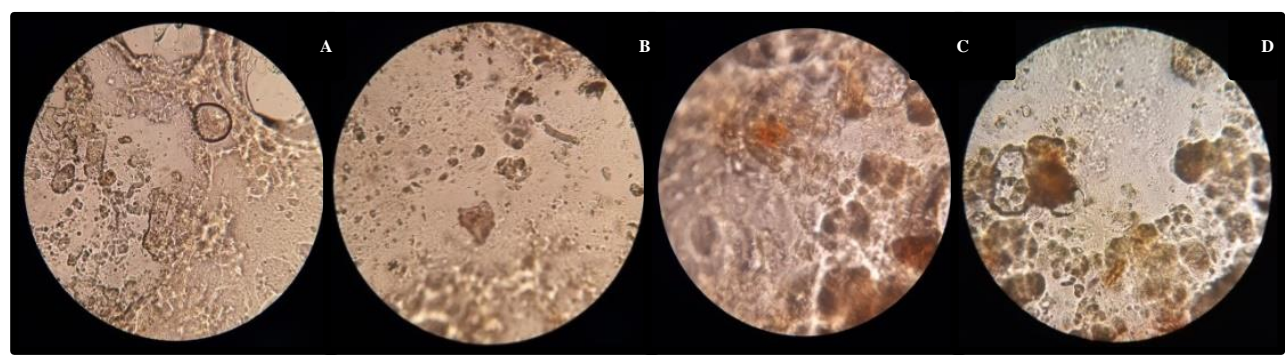

Fig 1. Microscopic images of edible coatings based on tamarind starch at the concentrations of $0.5 \%(A), 1.0 \%$ (B), 1.5 (C) and $2.0 \%$ (D) at objective 40x, UFCG, Pombal, 2018.

Table 2. Analysis of variance for weight loss $(\mathrm{WL})$, luminosity $\left(\mathrm{L}^{*}\right)$, chromaticity $\left(\mathrm{C}^{*}\right)$, hue angle $\left(\mathrm{H}^{\circ}\right)$, hydrogenation potential $(\mathrm{pH})$, soluble solids (SS), titratable acidity (AT), ratio (SS/AT), anthocyanins, flavonoids and vitamin C of Isabel grapes as a function of the concentration of the tamarind seed starch coating, CCTA/UFCG, Pombal, 2018.

\begin{tabular}{|c|c|c|c|c|c|c|c|}
\hline \multirow[t]{2}{*}{ Source of Variation } & \multirow[t]{2}{*}{ DF } & \multicolumn{3}{|c|}{ Medium square } & \multirow[b]{2}{*}{$\mathrm{H}$ 음 } & \multirow[b]{2}{*}{$\mathrm{pH}$} & \multirow[b]{2}{*}{ SS } \\
\hline & & $\mathrm{WL}$ & $L^{*}$ & $\mathrm{C}^{*}$ & & & \\
\hline Coating & 4 & $2.59^{* *}$ & $9.43^{* *}$ & $0.64^{* *}$ & $0.04^{* *}$ & $0.06^{\text {ns }}$ & $2.4^{* *}$ \\
\hline Error & 20 & - & - & - & - & - & - \\
\hline CV (\%) & - & 5.64 & 3.86 & 18.44 & 23.38 & 4.89 & 5,06 \\
\hline Source of Variation & $\mathrm{DF}$ & AT & SS/AT & Anthocyanins s & \multicolumn{2}{|c|}{ Flavonoides } & Vitamin C \\
\hline Coating & 4 & $0.05^{* *}$ & $54.04^{* *}$ & $0.43^{* *}$ & \multicolumn{2}{|c|}{$0.05^{\mathrm{ns}}$} & $1.79^{* *}$ \\
\hline Error & 20 & - & - & - & \multicolumn{2}{|l|}{-} & - \\
\hline CV (\%) & - & 10.36 & 14.32 & 5.47 & \multicolumn{2}{|l|}{10.79} & 10.71 \\
\hline
\end{tabular}

${ }^{\text {ns }}$ no significant, ${ }^{* *}$ significant to $1 \%$ of probability; ${ }^{*}$ significant to $5 \%$ of probability for the test $\mathrm{F}$; CV (variation coefficient).
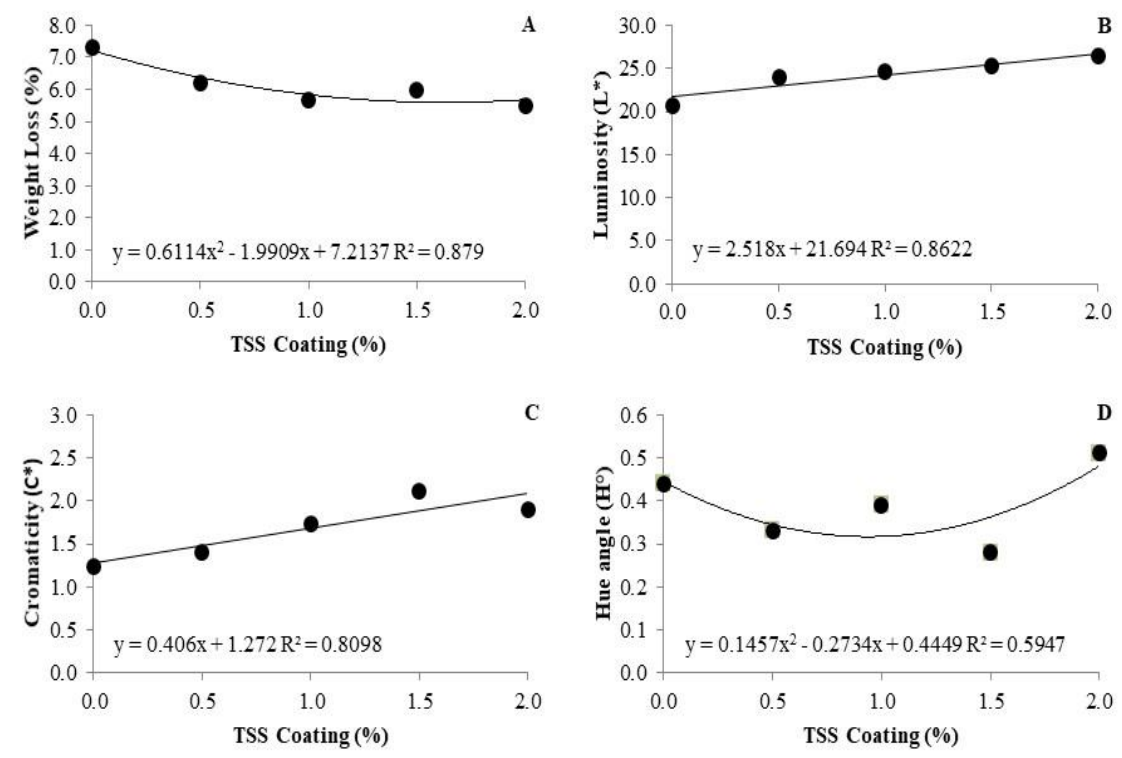

Fig 2. Weight loss (A), luminosity (B), chromaticity (C) and Hue angle (D) in Isabel grape treated with different concentrations of tamarind seed starch coating (TSS) after 12 days of storage at $12 \pm 2{ }^{\circ} \mathrm{C}$ and $85 \pm 5 \%$ RH, CCTA/UFCG, Pombal, 2018. 

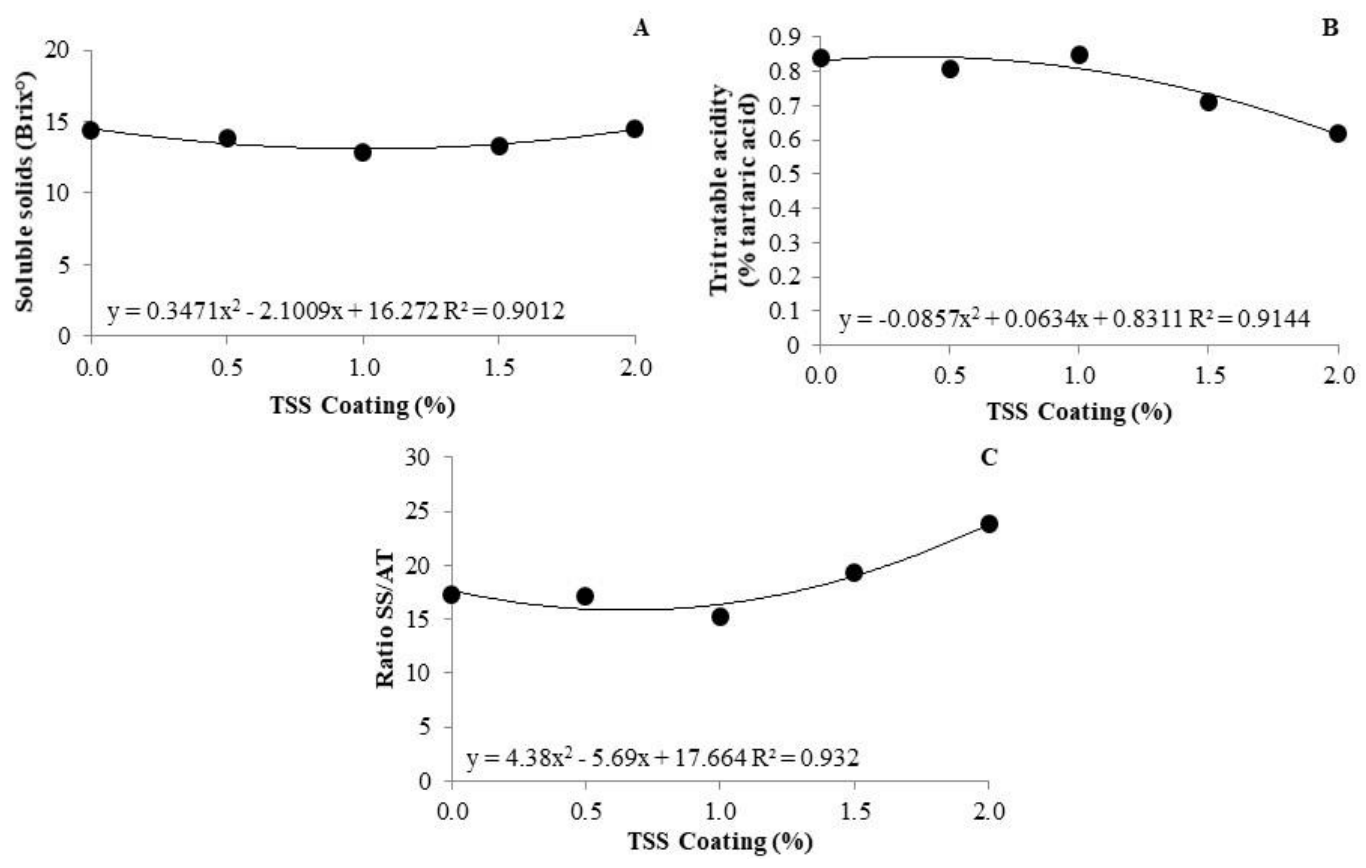

Fig 3. Soluble solids (A), Titratable Acidity (B) e Ratio (C) in Isabel grape treated with different concentrations of tamarind seed starch coating (TSS) after 12 days of storage at $12 \pm 2{ }^{\circ} \mathrm{C}$ and $85 \pm 5 \% \mathrm{RH}, \mathrm{CCTA} / \mathrm{UFCG}$, Pombal, 2018.
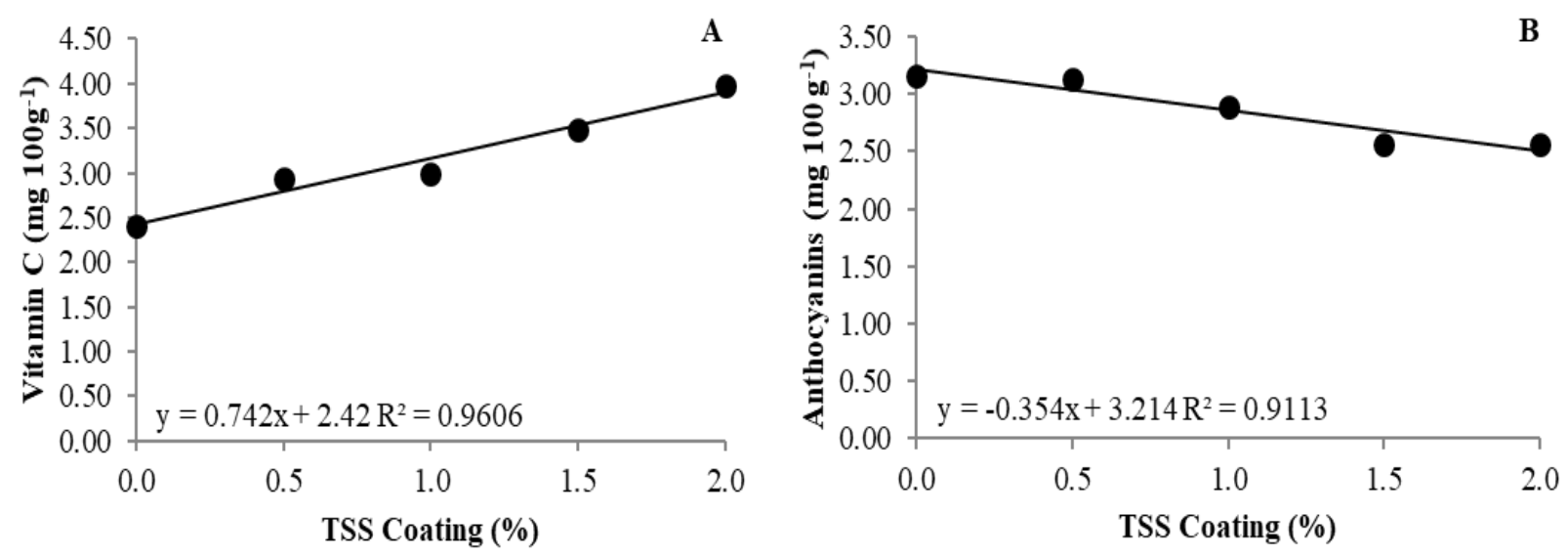

Fig 4. Vitamin $C(A)$ and Anthocyanins (B) in Isabel grape treated with different concentrations of tamarind seed starch coating (TSS) after 12 days of storage at $12 \pm 2^{\circ} \mathrm{C}$ and $85 \pm 5 \%$ RH, CCTA/UFCG, Pombal, 2018 .

Table grapes are considered non-climatic fruits and, with a relatively low physiological activity rate, berries are subject to spoilage and consequently to oxidative damage after harvest (Awad et al., 2015). Vitamin C can be easily oxidized, however in this work it has been proven that the higher the concentration of the TSS e coating, the greater the vitamin C retention, possibly resulting in a lower availability of oxygen throughout the storage period.

Silva et al. (2012), evaluating the post-harvest quality of Isabel grape with calcium chloride and modified atmosphere observed that the vitamin $\mathrm{C}$ content of the grape was higher in fruits kept under a modified atmosphere with refrigeration of $12{ }^{\circ} \mathrm{C}$ during 12 days of storage. Chen et al. (2019) reported that edible coatings $(1.0 \%$ chitosan and $1.5 \%$ poly- $\varepsilon$-lysine) inhibited vitamin C decline in "Kyoho" table grapes, maintaining their quality during storage at room temperature $\left(20^{\circ} \mathrm{C}\right)$.

The anthocyanin content of the grapes, at 12 days of storage, decreased as the coating concentrations increased, with estimated values of $3.03,2.85,2.68$ and $2.50 \mathrm{mg} 100 \mathrm{~g}$ -
1 , corresponding to respectively $0.5,1,1.5$ and $2.0 \%$ of AST, while control treatment obtained $3.21 \mathrm{mg} 100 \mathrm{~g}-1$ (Figure $4 \mathrm{~B})$. Anthocyanins are polyphenolic compounds present in table grapes that have important functional properties that promote human health (Champa et al., 2014). Anthocyanin accumulation in table grapes, especially in red to purple skin accessions, can be improved because the expression levels of genes related to anthocyanin biosynthesis are increased synergistically and coordinated by appropriate light and temperature (Azuma et al. , 2019).

The higher anthocyanin accumulation in the control treatment grapes may be related to its advanced maturation, which includes the synthesis of this pigment from glucose. Thus, the lowest anthocyanin concentrations occurred in edible-coated grapes, regardless of concentration, suggesting that the product has an inhibitory effect on fruit senescence (Melo et al., 2018). This result expresses the correlation of storage temperature associated with edible coating that may increase the inhibitory effects on grape senescence. 


\section{Plant material}

Cultivar Isabel hybrid table grapes were purchased from Patos Supply Center, located in Paraíba State, Northeast Region of Brazil. Grapes with pathogenic symptoms, mechanical or physiological damage were discarded.

\section{Experimental conduction}

The experiment was developed out at Federal University of Campina Grande (UFCG), Agri-food Science and Technology Center (CCTA), at Post-Harvesting Laboratory of Fruits and Vegetables, in November 2018. The transport the grapes to the laboratory was carried out in cardboard boxes $(640 \times 480$ $\mathrm{cm}$ ) coated with bubble wrap, in a single layer. The grapes were selected for quality, discarding those that suffered injuries during transportation. The fruits were washed in $1 \%$ detergent solution and sanitized with sodium hypochlorite at 200 ppm active chlorine for 20 minutes, rinsed with water and air dried.

\section{Tamarind seed starch extraction}

The starch for the preparation of the coverings was extracted from the tamarind seeds according to the methodology adapted by Leonel et al. (2003) where the seed embryo biomass was separated from the seed coat, homogenized with water, sieved, washed, decanted and dried to obtain the constant weight of starch.

\section{Experimental design and treatments}

The experiment was a completely randomized design, represented by five coating concentrations, with five replicates of 150 grams per experimental unit. The tamarind seed starch (AST) was diluted in $1 \mathrm{~L}$ of distilled water under constant stirring, heating to $70{ }^{\circ} \mathrm{C}$, followed by the suspensions at $40{ }^{\circ} \mathrm{C}$ plus Tween 20 ( $\left.1 \mathrm{~mL} . \mathrm{L}-1\right)$, mineral oil (0.5 mL.L-1) and glycerin (0.4mL.L-1) in order to emulsify and maximize the plasticity properties of the coating. Thus, the solutions were obtained at $0.5 ; 1.0 ; 1.5$ and $2.0 \%$ of AST. The control was composed only of fruits immersed in distilled water. The fruits were immersed in the solutions, dried at room temperature and stored in B.O.D. at $12 \pm 2{ }^{\circ} \mathrm{C}$ and $85 \pm$ $5 \% \mathrm{RH}$. The fruits were evaluated in the initial characterization and after 12 days of storage.

\section{Variables analyzed}

Weight loss: the fruits were weighed in a semi-analytical balance $( \pm 0.01 \mathrm{~g})$ and the results expressed in percentage losses, using the difference between the initial fresh mass and the final fresh mass after the storage period.

Color of the peel: Fruit peel color was measured with a chroma meter (Minolta Corp, model CR-400, Japan) with D65 standard illuminant, a viewing angle of $0^{\circ}$, and calibrated with a standard color (white), using the CIELab system. The luminosity (L*; $0=$ black; $100=$ white), chromaticity $\left(\mathrm{C}^{*}\right)$, and angle Hue $\left(\mathrm{h}^{\circ}\right)$ were measured in readings per fruit along the equatorial region.
Potential of Hydrogen $(\mathrm{pH})$ : measured by a digital peg for the direct reading of the homogenized pulp, according to IAL (2008).

Titratable Acidity (TA): 10 grams of homogenized pulp were diluted in $100 \mathrm{~mL}$ of distilled water and titrated with standard solution of $0.1 \mathrm{~N} \mathrm{NaOH}$, using phenolphthalein as indicator. The results were expressed as\% tartaric acid (IAL, 2008).

Soluble Solids (SS): measured directly in the homogenized pulp through a digital refractometer (model PR-100, Palette, Atago Co., LTD., Japan), whose results were expressed in oBrix (AOAC, 2012).

Ratio SS/AT: calculation of the ratio between soluble solids and total titratable acidity (SS/AT). The results were expressed in decimals.

Vitamin C: it was measured through Tillman's methods. We weighed $5 \mathrm{~g}$ of the sample, which was transferred into Erlenmeyer vials, in which the volume was completed for 45 $\mathrm{mL}$ with $0.5 \%$ of oxalic acid, whose titration was performed with Tillman's solution until the turning point (AOAC, 2012). Anthocyanins and Flavonoids: was based on the methodology proposed by Francis (1982), made in spectrophotometer reading at the wavelength of 535 for anthocyanins and 374 for flavonoids. The results were expressed as mg $100 \mathrm{~g}^{-1}$.

Statistical Analysis: The data were submitted for analysis of variance and regression through the Sisvar Program (Ferreira, 2014)

\section{Conclusions}

The results of this study indicate that the edible coatings of tamarind seed starch were effective in maintaining quality during the shelf life of the grapes. The $2 \%$ coating of tamarind seed starch was the most efficient, providing shelf life in grapes of 12 days when stored at $12 \pm 2{ }^{\circ} \mathrm{C}$ and $85 \pm$ $5 \% \mathrm{RH}$, and maintains the main aspects of quality, providing higher ratio SS/AT and vitamin C contents.

\section{Acknowledgments}

The authors thanks to CAPES and UFCG. The present work was realized with the support of Coordenação de Aperfeiçoamento de Pessoal de Nível Superior - Brazil (CAPES) - Finance Code 001

\section{References}

AOAC (2012) ASSOCIATION OF OFFICIAL ANALYTICAL CHEMISTS. Official Methods of Analysis of the Association of Official Analytical Chemists. 19 ed. Gaithersburg, Maryland.

Awad MA, Al-Qurashi AD, Mohamed SA (2015) Postharvest trans -resveratrol and glycine betaine treatments affect quality, antioxidant capacity, antioxidant compounds and enzymes activities of "El-Bayadi" table grapes after storage and shelf life. Sci Hort. 197:350-356.

Azuma A, Yakushiji H, Sato A (2019) Postharvest light irradiation and appropriate temperature treatment increase anthocyanin accumulation in grape berry skin. Post Bio Tec. 147:89-99.

Champa WAH, Gill MIS, Mahajan BVC, Arora NK (2014) Postharvest treatment of polyamines maintains quality and extends shelf-life of table grapes (Vitis vinifera L.) cv. Flame Seedless. Post Bio Tec. 91:57-63. 
Chen R, Wu P, Cao D, Tian H, Chen C, Zhu B (2019) Edible coatings inhibit the postharvest berry abscission of table grapes caused by sulfur dioxide during storage. Post Bio Tec. 152:1-8.

Duarte MH, Queiroz EZ, Rocha DA, Costa AC, Abreu CMP (2017) Qualidade de pitaia (Hylocereus undatus) submetida à adubação orgânica e armazenada sob refrigeração. Brazilian Journal of Food Technolgy, Campinas. 20:1-11.

Eom H, Chang Y, Lee E, Choi HD, Han J (2018) Development of a starch/gum-based edible coating for rice cakes to retard retrogradation during storage. LWT. 97:516-522.

Fakhouri FM, Martelli SM, Caon T, Velasco JI, Mei LHI (2015) Edible films and coatings based on starch/gelatin: Film properties and effect of coatings on quality of refrigerated Red Crimson grapes. Post Bio Tec. 109:57-64.

Ferreira DF (2014) Sisvar: a Guide for its Bootstrap procedures in multiple comparisons. Ciên e agro, Lavras, 38:109-112.

Francis FJ (1982) Analysis of anthocyanins. In: MARKAKIS, P. (Ed.). Anthocyanins as food colors. New York: Academic Press, 181-207.

Guerra ICD, Oliveira PDL, Santos MMF, Lúcio ASSC, Tavares JF, Barbosa-Filho JM, Madruga MS, Souza EL (2016) The effects of composite coatings containing chitosan and Mentha ( piperita L. or $\mathrm{x}$ villosa Huds) essential oil on postharvest mold occurrence and quality of table grape cv. Isabella. Innovative Food Science \& Emerging Technologies. 34:112-121.

IAL (2008) Instituto Adolfo Lutz. Métodos físico-químicos para análise de alimentos. 4 ed. São Paulo: Instituto Adolfo Lutz.

Kai KC (2009) Extração e caracterização de xiloglucanas de tamarindus Indica. Monografia (Graduação) - Trabalho de conclusão do Curso de Ciências Biológicas, Departamento de Bioquímica e Biologia Molecular, Universidade Federal do Paraná, Curitiba.

Lemes GF, Marchiore NG, Moreira TFM, Da Silva TBV, Sayer C, Shirai MA, Gonçalves OH, Gozzo AM, Leimann FV (2017) Enzymatically crosslinked gelatin coating added of bioactive nanoparticles and antifungal agent: Effect on the quality of Benitaka grapes. LWT. 84:175-182.

Leonel M, Sarmento SBS, Cereda MP, Cãmara FLA (2003) Extração e caracterização de amido de jacatupé (Pachyrhizus ahipa). Ciên Tec Ali. 23(3):362-365.

Mascarenhas RJ, Silva SM, Lima MAC, Mendonça RMN, Holschuh HJ (2012) Characterization of maturity and quality of Brazilian apirenic grapes in the São Francisco river Valley. Food Sci Tec. 32:26-33.

Maurer LH, Bersch AM, Santos RO, Trindade SC, Costa EL, Peres MM, Malmann CA, Schneider M, Bochi VC, Sautter CK, Emanuelli T (2017) Postharvest UV-C irradiation stimulates the non-enzymatic and enzymatic antioxidant system of "Isabel" hybrid grapes (Vitis labrusca $\times$ Vitis vinifera L.). Food Res Int. 102:738-747.
Melo NFCB, Soares BLM, Diniz KM, Leal CF, Canto D, Flores MAP, Tavares-Filho JHC, Galembeck A, Stamford TLM, Stamford-Arnaud TM, Stamford TCM (2018) Effects of fungal chitosan nanoparticles as eco-friendly edible coatings on the quality of postharvest table grapes. Post Bio Tec. 139:56-66.

Oh YA, Oh YJ, Song AY, Won JS, Song KB, Min SC (2017) Comparison of effectiveness of edible coatings using emulsions containing lemongrass oil of different size droplets on grape berry safety and preservation. LWT. 75:742-750.

Onias EA, Araújo RHCR, Queiroga TB, Teodosio AEMM, Onias EA, Ferreira APN, Rodrigues MHBS, Oliveira AMF, Medeiros MLS (2019) Coating Guava Postharvest With the Use of Starch of Tamarind Seed and Pomegranate Seed Oil. Jour of Agri Sci. 11:313-324.

Pereira SS (2017) Compostos bioativos e caracterização de sementes de frutas tropicais. Dissertação (Mestrado) Programa de Pós-Graduação em Ciência dos Alimentos, Universidade Federal de Lavras, Lavras.

Poverenov E, Danino S, Horev B, Granit R, Vinokur Y, Rodov V (2013) Layer-by-Layer Electrostatic Deposition of Edible Coating on Fresh Cut Melon Model: Anticipated and Unexpected Effects of Alginate-Chitosan Combination. Food and Bio Tec. 7:1424-1432.

Silva RS, Silva SM, Dantas AL, Mendonça RMN, Guimarães GHC (2012) Qualidade de uva "Isabel" tratada com cloreto de cálcio em pós-colheita e armazenada sob atmosfera modificada. Rev Bra de Frut. 34:50-56.

Stocco AF, Diaz ME, Rodríguez Romera MC, Mercado LA, Rivero ML, Ponsone ML (2019). Biocontrol of postharvest Alternaria decay in table grapes from Argentina. Biological Control. 134:114-122.

Vicentino SL, Floriano PA, Dragunski DC, Caetano J (2011) Filmes de amidos de mandioca modificados para recobrimento e conservação de uvas. Quí Nov. 34:13091314.

Wang $X$, He $Q$, Matetic $M$, Jemric $T$, Zhang X (2017) Development and evaluation on a wireless multi-gassensors system for improving traceability and transparency of table grape cold chain. Comp Elec Agri. 135:195-207.

Yamamoto LY, Assis AM, Roberto SR, Bovolenta YR, Nixdorf SL García-Romero E, Gómez-Alonso S, Hermosín-Gutiérrez, I (2015) Application of abscisic acid (S-ABA) to cV. Isabel grapes (Vitis vinifera $\times$ Vitis labrusca) for color improvement: Effects on color, phenolic composition and antioxidant capacity of their grape juice. Food Res Int. 77:572-583.

Yousuf B, Qadri OS, Srivastava AK (2018) Recent developments in shelf-life extension of fresh-cut fruits and vegetables by application of different edible coatings: a review. LWT. 89:198-209.

Zhao Y (2019) Edible Coatings for Extending Shelf-Life of Fresh Produce During Postharvest Storage. Enc Food Sec Sus. 2:506-510. 